\title{
Novel Aminopyrene Substituted Monospiro/Dispiro Cyclotriphos- phazenes: Synthesis, Characterization and Chemosensor Properties
}

\author{
Elif Şenkuytu \\ Department of Chemistry, Faculty of Science, Gebze Technical University, Gebze, Turkey \\ senkuytu@gtu.edu.tr \\ Received: 27 February 2018 \\ Accepted: 05 June 2018 \\ DOI: $10.18466 /$ cbayarfbe.399162
}

\begin{abstract}
In the present work, the novel aminopyrene substituted monospiro/dispiro cyclotriphosphazenes (6 and 7 ) have been synthesized. This compounds were characterized general spectroscopic techniques such as mass, ${ }^{1} \mathrm{H}$ and ${ }^{31} \mathrm{P}$ NMR spectrometry. The photophysical and chemosensor properties toward various metals $\left(\mathrm{Fe}^{3+}\right.$, $\left.\mathrm{Cr}^{3+}, \mathrm{Co}^{2+}, \mathrm{Al}^{3+}, \mathrm{Hg}^{+}, \mathrm{Mn}^{2+}, \mathrm{Ni}^{2+}, \mathrm{Cu}^{2+}, \mathrm{Cd}^{2+}, \mathrm{Zn}^{2+}, \mathrm{Mg}^{2+}, \mathrm{Ca}^{2+}, \mathrm{Ba}^{2+}, \mathrm{Li}^{+}, \mathrm{Na}^{+}, \mathrm{K}^{+}, \mathrm{Cs}^{+}\right)$in THF solutions of aminopyrene substituted compounds were investigated by fluorescence spectroscopy. The metal sensing results showed that compounds 6 and 7 can be candidate fluorescent chemosensors for $\mathrm{Cu}^{2+}$ and $\mathrm{Fe}^{3+}$ ions due to their displaying high selectivity and low limit of detection.

Keywords: Cyclotriphosphazene, Monospiro, Dispiro, 1-Aminopyrene, Photophysical Properties.
\end{abstract}

\section{Introduction}

Phosphazenes, - $\left[\mathrm{N}=\mathrm{PR}_{2}\right]$-, are a significant class of inorganic chemistry and they can be represented in various form such as linear short-chain, cyclic, or high-molecularweight polymers [1]. Hexachlorocyclotriphosphazene, which has six active chlorine atoms in its ring, is known for its rigid inorganic platform for multifunctional molecular arrangements. These chlorine atoms can easily displace with reagents having different properties [2]. These properties cause researchers to choose this compound as the main skeleton. The properties of the cyclotriphosphazenes may modify according to the number and properties of the functional groups. Thus, the specific physical and chemical properties of cyclotriphosphazene derivatives lead to differences in the application areas of these compounds. Some of these applications are anticancer/antimicrobial agents, organic light emitting diodes (OLEDs), flame retardants, liquid crystals and fluorescent chemosensor [3-6]. In particular, studies related to fluorescent chemosensor applications of cyclotriphosphazenes have increased $[7,8]$.

The development of sensitive fluorescent chemosensors has been attracted considerable attention in recent years due to the increase of important of applications in various fields such as biochemistry, environment [9]. In particular, the importance of chemosensors for iron and copper ions has received great interest in the past few decades due to their important role in many biological and environmental processes $[10,11]$. Iron is the most abundant transition metal found of mammalians cellular systems. For example, $\mathrm{Fe}^{3+}$ is used for oxygen metabolism, RNA/DNA synthesis, as cellular metabolism and enzyme catalysis [12]. Besides, copper $\left(\mathrm{Cu}^{2+}\right)$, which the third most important element in the human body, is used in many metabolic events, such as various redox processes and enzyme functions [13]. The iron and copper deficiency or excess can cause to various diseases in the human body such as anemia, hemochromatosis, liver damage, diabetes, Parkinson's, Alzheimer's, serious neurodegenerative diseases, Menkes and Wilson's diseases, liver damage, childhood cirrhosis and cancer [14, 15]. Therefore, it is important that copper and iron ions in environmental and biological samples can be detected sensitively and selectively by different analytical methods. Among these methods, fluorescent sensor technology is widely used for the detection of metal ions in organic or aqueous media owing to the simplicity and speed of the method. In recent years, the literature has reported a large number of fluorescent chemosensor probes for $\mathrm{Cu}^{2+}$ and $\mathrm{Fe}^{3+}$ detection using this method [16-18].

In this current study, the aim was to develop novel fluorescent chemosensors for the detection of metal ions. Studies on the metal binding abilities of pyrene molecules have shown that they might let to the use of new synthesized aminoprene based cyclotriphosphazene compounds as chemosensor. Selectivity is the most important parameter for fluorescence sensor application and a chemosensor has 
to be high selective toward the analyte between other competitive species. In this framework, the aminopyrene substituted monospiro/dispiro cyclotriphosphazene compounds $(6,7)$ have been designed and successfully synthesized. The synthesized cyclotriphosphazene derivatives were characterized general spectroscopic techniques such as ${ }^{1} \mathrm{H},{ }^{31} \mathrm{P}$ NMR and mass spectrometry. In addition, the photophysical properties of new compounds and chemosensor behavior were examined using UV-Vis electronic and fluorescence spectroscopy.

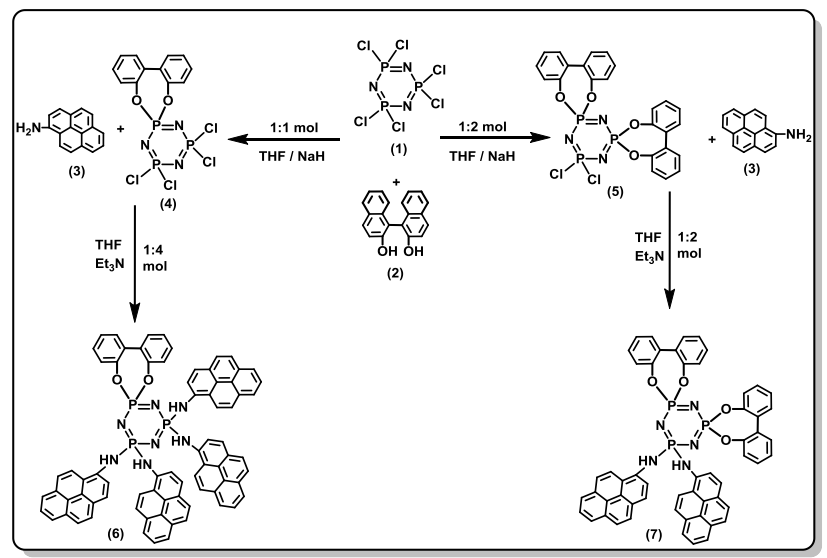

Scheme 1. Aminopyrene substituted monospiro and dispiro cyclotriphosphazene derivatives.

\section{Metarials and Methods}

\subsection{Metarials}

The deuterated solvent $\left(\mathrm{CDCl}_{3}\right)$ for NMR spectroscopy, silica gel, tetrahyrofuran, dichloromethane, n-hexane and metal chlorides were provided from Merck. Following chemicals were obtained from Sigma Aldrich; hexachlorocyclotriphosphazene, 1-Aminopyrene, 2,2'-Biphenol and 1,8,9-Anthracenetriol for the MALDI matrix was obtained from Fluka. All other chemicals used for the synthesis were reagent grade unless otherwise specified.

\subsection{Equipment}

Electronic absorption spectra were recorded with a Shimadzu 2101 UV spectrophotometer in the UV-visible region. Fluorescence excitation and emission spectra were recorded on a Varian Eclipse spectrofluorometer using 1 $\mathrm{cm}$ pathlength cuvettes at room temperature. The fluorescence lifetimes were obtained using Horiba- Jobin-YvonSPEX Fluorolog 3-2iHR instrument with Fluoro Hub-B Single Photon Counting Controller at an excitation wavelength of $470 \mathrm{~nm}$. Signal acquisition was performed using a TCSPC module (NanoLED -390 emitting $390 \mathrm{~nm}$ ). Mass spectra were acquired in linear modes with average of 50 shots on a Bruker Daltonics Microflex mass spectrometer (Bremen, Germany) equipped with a nitrogen UV-Laser operating at $337 \mathrm{~nm} .{ }^{1} \mathrm{H}$ and ${ }^{31} \mathrm{P}$ NMR spectra were recorded in $\mathrm{CDCl}_{3}$ solutions on a Varian $500 \mathrm{MHz}$ spectrometer. Analytical thin layer chromatography (TLC) was performed on silica gel plates (Merck, Kieselgel $60 \AA$, 0.25 $\mathrm{mm}$ thickness) with $\mathrm{F}_{254}$ indicator. Column chromatography was performed on silica gel (Merck, Kieselgel $60 \AA$, 230-400 mesh). Suction column chromatography was performed on silica gel (Merck, Kieselgel $60 \AA$, $70-230$ mesh).

\subsection{Synthesis}

\subsubsection{Synthesis of compounds 4 and 5}

Monospiro(4)/dispiro(5) 2,2'-biphenoxy substituted cyclotriphosphazene compounds were synthesized according to literature [19].

2.3.2. Reaction of monospiro 2,2'-biphenoxy (4) substituted cyclotriphosphazene with 1-aminopyrene (3) in a 1:4 ratio to form compound 6

Monospiro 2,2'-biphenoxy substituted cyclotriphosphazene (4) $(100 \mathrm{mg}, 0.22 \mathrm{mmol})$ and triethylamine (90 $\mathrm{mg}, 0.88 \mathrm{mmol}$ ) were dissolved in $30 \mathrm{~mL}$ of tetrahyrofuran in a $100 \mathrm{~mL}$ reaction flask. 1-Aminopyrene $(3)(180 \mathrm{mg}$, $0.88 \mathrm{mmol})$ in tetrahyrofuran $(20 \mathrm{~mL})$ was added to the stirred solution. The reaction followed with TLC on silica gel plates using $n$-hexane/THF (2:1) as mobile phase. The reaction was stopped after mixing at room temperature for 3 days and the reaction mixture was filtered and the solvent was removed under low pressure. The obtained colorless oily product was purified with column chromatography using $n$-hexane / THF (2: 1) as mobile phase. Compound 6 (100 mg, $0.106 \mathrm{mmol}, \%$ 61). Anal. Calc. (\%) for $\mathrm{C}_{76} \mathrm{H}_{48} \mathrm{~N}_{7} \mathrm{O}_{2} \mathrm{P}_{3}: \mathrm{C}, 77.09 ; \mathrm{H}, 4.09 ; \mathrm{N}, 8.28$, found $\mathrm{C}, 77.07$; $\mathrm{H}, 4.07$; N, 8.25. MS (Maldi-TOF) m/z Calc. 1184.19; found $1184.00[\mathrm{M}]^{+}$(Fig.S1a). ${ }^{31} \mathrm{P}$ NMR $\left({ }^{1} \mathrm{H}\right.$ decoupled) $\left(202 \mathrm{MHz}, \mathrm{CDCl}_{3}\right) \mathrm{P}(\mathrm{O} \text {-spiro })_{2} \delta=25.01 \mathrm{ppm}\left(1 \mathrm{P},{ }^{2} \mathrm{~J}_{\mathrm{P}-\mathrm{P}}=\right.$ $68.01 \mathrm{~Hz},) ; \mathrm{P}(\mathrm{NHPyrn})_{2} \delta=8.81 \mathrm{ppm}\left(2 \mathrm{P},{ }^{2} \mathrm{~J}_{\mathrm{P}-\mathrm{P}}=68.01 \mathrm{~Hz}\right)$ (Fig. S2a). ${ }^{1} \mathrm{H}$ NMR $\left(500 \mathrm{MHz}, \mathrm{CDCl}_{3}, 298 \mathrm{~K}\right): \delta \mathrm{H}$ ppm, 8.30-7.51 (m, 44H, Ar-CH); 5.92-6.05 (m, 4H, NH).

2.3.2. Reaction of dispiro 1,1'-bi-2-naphthol (5) substituted cyclotriphosphazene with 1-aminopyrene (3) in a 1:2 ratio to form compound 7

Dispiro 2,2'-biphenoxy substituted cyclotriphos-phazene (5) $(100 \mathrm{mg}, 0.17 \mathrm{mmol})$ and triethylamine $(40 \mathrm{mg}, 0.35$ $\mathrm{mmol}$ ) were dissolved in $30 \mathrm{~mL}$ of tetrahyrofuran in a 100 $\mathrm{mL}$ reaction flask. 1-Aminopyrene $(3)(75 \mathrm{mg}, 0.35 \mathrm{mmol})$ in THF $(20 \mathrm{~mL})$ was added to the stirred solution. The reaction followed with TLC on silica gel plates using $n$-hexane/THF (5:1) as mobile phase. The reaction was stopped after mixing at room temperature for 5 days and the reaction mixture was filtered and the solvent was removed under low pressure. The obtained colorless oily product was purified with column chromatography using $n$-hexane / THF (5: 1) as mobile phase. Compound 7 (150 mg, 0.126 
mmol, \% 60). Anal. Calc. (\%) for $\mathrm{C}_{56} \mathrm{H}_{36} \mathrm{~N}_{5} \mathrm{O}_{4} \mathrm{P}_{3}$ : C, 71.87; $\mathrm{H}, 3.88$; N, 7.48, found $\mathrm{C}, 71.85 ; \mathrm{H}, 3.85$; N, 7.46. MS (Maldi-TOF) $\mathrm{m} / \mathrm{z}$ Calc. 935.86; found $936.93[\mathrm{M}+\mathrm{H}]^{+}$ (Fig.S1b). ${ }^{31} \mathrm{P}$ NMR $\left({ }^{1} \mathrm{H}\right.$ decoupled) (202 MHz, $\left.\mathrm{CDCl}_{3}\right)$ $\mathrm{P}(\mathrm{O} \text {-spiro })_{2} \quad \delta=25.54 \mathrm{ppm}\left(2 \mathrm{P},{ }^{2} \mathrm{~J}_{\mathrm{P}-\mathrm{P}}=72.23 \mathrm{~Hz},\right)$; $\mathrm{P}(\mathrm{NHPyrn})_{2} \delta=9.03 \mathrm{ppm}\left(1 \mathrm{P},{ }^{2} \mathrm{~J}_{\mathrm{P}-\mathrm{P}}=72.23 \mathrm{~Hz}\right)$ (Fig. S2b). ${ }^{1} \mathrm{H}$ NMR (500 MHz, $\left.\mathrm{CDCl}_{3}, 298 \mathrm{~K}\right): \delta \mathrm{H} \mathrm{ppm}, 8.47$ (d, J = $7.71 \mathrm{~Hz}, 2 \mathrm{H}, \mathrm{Ar}-\mathrm{CH}) ; 8.20$ (d, J = 7.89 Hz, 2H, Ar-CH); 8.01 (d, J = 6.88 Hz, 2H, Ar-CH); 7.95-7.79 (m, 10H, Ar$\mathrm{CH}) ; 7.69$ (d, J = 8.99 Hz, 2H, Ar-CH); 7.56 (d, J = 7.07 $\mathrm{Hz}, 4 \mathrm{H}, \mathrm{Ar}-\mathrm{CH}) ; 7.36-7.25$ (m, 8H, Ar-CH); 7.17 (d, J = $7.08 \mathrm{~Hz}, 4 \mathrm{H}, \mathrm{Ar}-\mathrm{CH}), 5.94$ (d, J = 9.19 Hz, 2H, NH).

\section{Result and Discussion}

3.1. Synthesis and NMR Characterization of Aminopyrene Substituted monospiro/dispiro Cyclotriphosphazenes (6 and 7)

In this work, novel aminopyrene substituted monospiro/dispiro cyclotriphosphazene compounds $(6,7)$ have been successfully synthesized and their synthesis strategies are summarized in Scheme 1. In this framework, firstly, monospiro/dispiro 2,2'-biphenoxy substituted cyclotriphosphazenes $(4,5)$ were prepared according of the literature [19]. The target compounds 6 and 7 (aminopyrene substituted cyclotriphosphazenes) were synthesized from compounds 4 and $\mathbf{5}$ with the 1-aminopyrene by nucleophilic substitution reactions (Scheme 1). The obtained all compounds were completely characterized using spectroscopic techniques such as ${ }^{1} \mathrm{H},{ }^{31} \mathrm{P} \mathrm{NMR}$ and mass spectrometry and structure analysis data of new compounds were presented in synthesis. It is clear that the molecular ion peaks (1184.00 and 936.93, respectively) observed in the mass spectra of the compounds $(6,7)$ support the proposed structures (Fig.S1). The proton decoupled ${ }^{31} \mathrm{P}$ NMR spectra of compounds $(6,7)$ were depicted as Figure S2. The ${ }^{31} \mathrm{P}$ NMR spectra of compounds $(6,7)$ were observed two different spin systems $\left(\mathrm{AX}_{2}\right.$ for compound $\mathbf{6}, \mathrm{A}_{2} \mathrm{X}$ for compound 7). Because there is two different phosphorus nuclei in the cyclotriphosphazene ring, as expected. The proton decoupled ${ }^{31} \mathrm{P}$ NMR spectrum of the both compounds $(6,7)$ were seen two signal. The signals consisted of one triplet for the $-\mathrm{P}(\mathrm{O}$-spiro $)$ groups $(\delta=25.01 \mathrm{ppm})$ and a doublet for the $-\mathrm{P}(\mathrm{NHPyrn})_{2}$ groups $(\delta=8.81 \mathrm{ppm})$ for compound $\mathbf{6}$, one doublet for the $-\mathrm{P}(\mathrm{O}$-spiro $)$ groups $(\delta=25.54 \mathrm{ppm})$ and one triplet for the $-\mathrm{P}(\mathrm{NHPyrn})_{2}$ groups $(\delta=9.03 \mathrm{ppm})$ for compound 7. In addition, the aromatic protons for compounds 6 and 7 in the ${ }^{1} \mathrm{H}$ NMR spectra were observed at between 8.47 and $7.17 \mathrm{ppm}$ and some of them were distinguishable from each other.

\subsection{Spectral Studies}

The absorption and fluorescence properties of two novel aminopyrene substitute monospiro/dispiro cyclotriphos- phazene compounds $(6,7)$ were examined in various solvents such as acetonitrile, acetone, dichloromethane, chloroform, tetrahydrofuran and methanol at room temperature (Fig.S3-S6). The Maximum absorbance wavelengths both compounds were observed approximately at 250, 295, 3450 and $395 \mathrm{~nm}$ in tetrahydrofuran (Fig. 1). The fluorescence emission spectra obtained for compounds $\mathbf{6}$ and $\mathbf{7}$ in the same solutions were seen two shoulders almost at 395 and $420 \mathrm{~nm}$ which belong to monomer pyrene emission, together with excimer emission band consisting at around $485 \mathrm{~nm}$ (Fig.1). The eximer emission band density of compound 6 was seen higher than the emission band density of compound 7 at the same wavelength. The increase in noncovalent $\pi-\pi$ and $\mathrm{CH}-\pi$ stacking interactions between the aminopyrene units in the cyclotriphosphazene ring of compound $\mathbf{6}$ caused an increase in intramolecular excimer emission intensity of compound 6 . In addition, the molar extinction coefficients of compounds $\mathbf{6}$ and $\mathbf{7}$ were calculated from the absorption spectra of the compounds at different concentrations (Table 1, Fig.S7, S8).

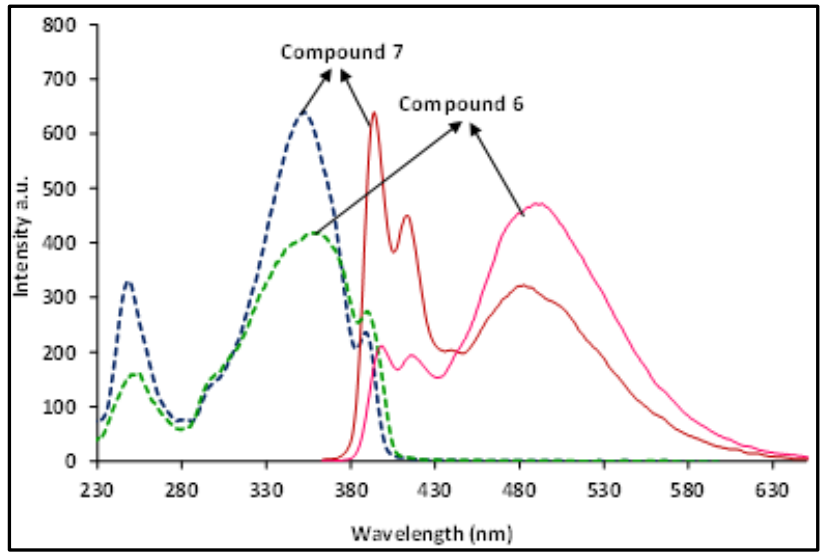

Figure 1. Excitation (left lines) and emission spectra (right lines) of Compound $\mathbf{6}$ and $\mathbf{7}$ in tetrahydrofuran.

\subsection{Chemosensor Studies}

This work was particularly focused on the examination of metal detecting behaviors of the novel synthesized aminopyrene substitute monospiro/dispiro cyclotriphosphazene compounds $(6,7)$ in solution. The metal binding properties (chemosensor) of the synthesized novel compounds $(6,7)$ against to various of metal ions $\left(\mathrm{Fe}^{3+}, \mathrm{Cr}^{3+}\right.$, $\mathrm{Co}^{2+}, \mathrm{Al}^{3+}, \mathrm{Hg}^{+}, \mathrm{Mn}^{2+}, \mathrm{Ni}^{2+}, \mathrm{Cu}^{2+}, \mathrm{Cd}^{2+}, \mathrm{Zn}^{2+}, \mathrm{Mg}^{2+}, \mathrm{Ca}^{2+}$, $\mathrm{Ba}^{2+}, \mathrm{Li}^{+}, \mathrm{Na}^{+}, \mathrm{K}^{+}, \mathrm{Cs}^{+}$) were investigation using the fluorescence spectroscopy. The fluorescence studies were performed in tetrahydrofuran solutions of the cyclotriphosphazene compounds $(6,7)$. Aqueous solutions of metal chlorides prepared at room temperature were used as source of metal ions. The working concentrations were prepared as $5 \mu \mathrm{M}$ for compounds $\mathbf{6}$ and 7 to investigate the fluorescence properties of the new compounds. The fluorescence 
emission spectra, which obtained by adding $10 \mu \mathrm{L}$ of 0.1 $M$ different competitive metal ions of these compounds in THF solutions, were remained nearly unchanged upon separately addition of the metal solutions except for copper (II) and iron (III) (Fig. 2, Fig. S9). The binding of the metal ions $\left(\mathrm{Cu}^{2+}\right.$ and $\left.\mathrm{Fe}^{3+}\right)$ causes changed in the fluorescence spectra or quench the fluorescence of pyrene molecule as expected. Besides, when the selectivity of $\mathrm{Cu}^{2+}$ and $\mathrm{Fe}^{3+}$ ions were tested in the presence of other metal ions, the results showed that other metal ions were insignificant for detection of cupper $\left(\mathrm{Cu}^{2+}\right)$ and iron $\left(\mathrm{Fe}^{3+}\right)$ ions. Namely, the results clearly show that compounds $\mathbf{6}$ and $\mathbf{7}$ can be sensitive fluorescent chemosensors for $\mathrm{Cu}^{2+}$ and $\mathrm{Fe}^{3+}$ ions. Determination of stoichiometry between the novel aminopyrene substituted monospiro/dispiro cyclotriphosphazene chemosensors and metal ions was done by the Continuous Variation method. According to Job Plot results, the molar fraction for $\mathrm{Fe}^{3+}$ cation was seen as 0.3 and 0.5 for compounds 6 and 7; for $\mathrm{Cu}^{2+}$ cation was observed as 0.3 for compounds 6 and 7 , respectively.

The compound 6 and $\mathrm{Cu}^{2+} / \mathrm{Fe}^{3+}$ cations preferred 2:1(L/M) stoichiometry for complexes among the compound and $\mathrm{Cu}^{2+} / \mathrm{Fe}^{3+}$ ions, respectively (Fig. S10). In addition, the compounds 7 and $\mathrm{Cu}^{2+} / \mathrm{Fe}^{3+}$ cations preferred 2:1(L/M)/1:1(L/M) stoichiometry for complexes, respectively (Fig. 3). Fluorescence titration experiments with $\mathrm{Cu}^{2+}$ and $\mathrm{Fe}^{3+}$ were performed using fluorescence spectroscopy in order to get more information into fluorescence properties changes of compounds $(\mathbf{6}, \mathbf{7})$ in the presence $\mathrm{Cu}^{2+}$ and $\mathrm{Fe}^{3+}$ ions. The fluorescence emission intensity alters of compounds 6, 7 are shown in Figure 4 and S11 that included $0-50 \mu \mathrm{M}$ concentrations of $\mathrm{Fe}^{3+}$ and $0-100 \mu \mathrm{M}$ concentrations $\mathrm{Cu}^{2+}$. In addition, considering to the fluorescence titration graph the sensing limits of sensors were calculated by the $3 \sigma / \mathrm{k}$ equation as $7.39 \mu \mathrm{M}$ and $2.16 \mu \mathrm{M}$ for $\mathrm{Fe}^{3+}$ (for compounds 6,7) and $18.13 \mu \mathrm{M}$ and $5.64 \mu \mathrm{M}$ (for compound 6,7) for $\mathrm{Cu}^{2+}$, respectively (Table 1, Fig. 5 and S12) [20].

Table 1. Photophysical properties of pyrene substituted cyclotriphosphazenes ${ }^{a}$.

\begin{tabular}{|c|c|c|c|c|}
\hline Comp. & $\begin{array}{l}\lambda_{a b}, \\
\mathbf{n m}\end{array}$ & $\begin{array}{l}\lambda_{e m}, \\
\mathbf{n m}\end{array}$ & $\begin{array}{c}\epsilon^{b}, 10^{4} \\
M^{-1} \mathrm{~cm}^{-}\end{array}$ & $\begin{array}{c}\text { Det. Lim. } \\
\mu \mathrm{M}\end{array}$ \\
\hline \multirow[b]{2}{*}{6} & \multirow{2}{*}{$\begin{array}{l}255,295, \\
350,395\end{array}$} & \multirow{2}{*}{$\begin{array}{c}400,420 \\
485\end{array}$} & \multirow{2}{*}{8.39} & $7.391\left(\mathrm{Fe}^{3+}\right)$ \\
\hline & & & & $18.134\left(\mathrm{Cu}^{2+}\right)$ \\
\hline \multirow{2}{*}{7} & \multirow{2}{*}{$\begin{array}{l}250,295, \\
355,395\end{array}$} & \multirow{2}{*}{$\begin{array}{c}393,415 \\
490\end{array}$} & \multirow{2}{*}{5.17} & $2.166\left(\mathrm{Fe}^{3+}\right)$ \\
\hline & & & & $5.641\left(\mathrm{Cu}^{2+}\right)$ \\
\hline
\end{tabular}

${ }^{\mathrm{a}}$ Tetrahydrofuran. ${ }^{\mathrm{b}}$ Molar extinction coefficients.

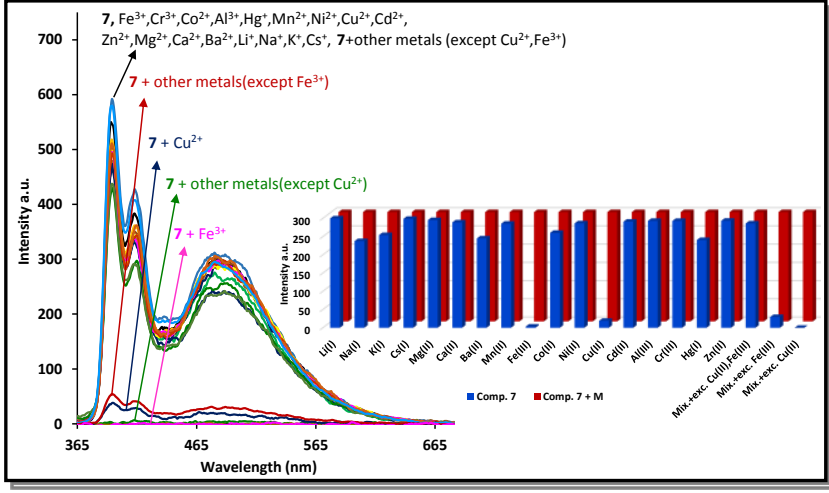

Figure 2. The fluorescence emission spectra of Compound $7(5 \mu \mathrm{M}$ in THF) after addition of $10 \mu \mathrm{L}$ of $0.1 \mathrm{M}$ different metal ions (Excitation wavelength $=350 \mathrm{~nm}$ ).
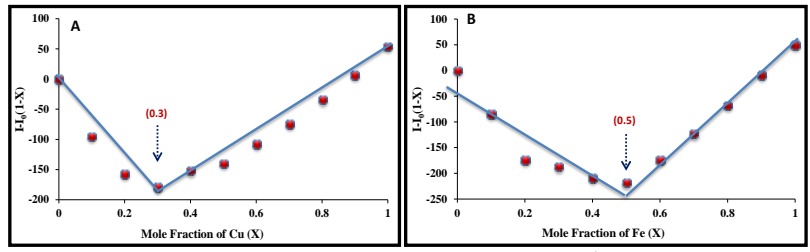

Figure 3. The Job's plot of graphic (a) $\mathrm{Cu}^{2+}+$ compound 7 complex, (b) $\mathrm{Fe}^{3+}+$ compound 7 complex in THF.
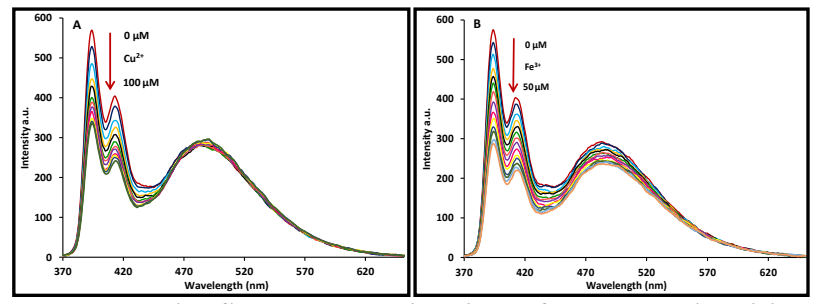

Figure 4. The fluorescence titration of compounds with different amount of (a) $\mathrm{Cu}^{2+}$ and (b) $\mathrm{Fe}^{3+}(\mathrm{C}=5 \mu \mathrm{M}$ in terahydrofuran, exc. $=350 \mathrm{~nm}$ ).

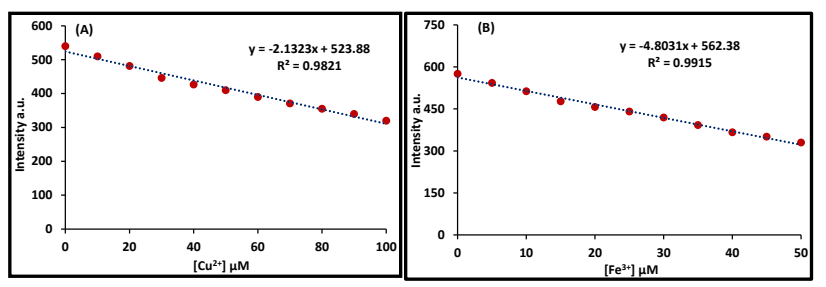

Figure 5. The calibration curve of fluorescence intensity for Compound 7 in $5 \mu \mathrm{M}$ in THF (a) $\mathrm{Cu}^{2+}(0-100 \mu \mathrm{M})$, (b) $\mathrm{Fe}^{3+}(0-50 \mu \mathrm{M})$.

\section{Conclusion}

In conclusions, two new aminopyrene substituted monospiro/dispiro cyclotriphosphazene compounds $(\mathbf{6}, 7)$ have been successfully synthesized. All the structural properties of these synthesized novel compounds were confirmed using mass, ${ }^{1} \mathrm{H}$ and ${ }^{31} \mathrm{P}$ NMR spectrometry. The absorption 
and fluorescence properties of the new compounds were examined using UV-Vis and fluorescence spectroscopies. While the absorption bands were observed at approximately the range at 250-395 nm for compound 6 and 7 in tetrahydrofuran solutions, the fluorescence emission wavelength of the same compounds were observed at 395, 420 and $485 \mathrm{~nm}$ in same solution. The chemosensor properties of compounds $(6,7)$ against to various of metal ions $\left(\mathrm{Fe}^{3+}\right.$, $\mathrm{Cr}^{3+}, \mathrm{Co}^{2+}, \mathrm{Al}^{3+}, \mathrm{Hg}^{+}, \mathrm{Mn}^{2+}, \mathrm{Ni}^{2+}, \mathrm{Cu}^{2+}, \mathrm{Cd}^{2+}, \mathrm{Zn}^{2+}, \mathrm{Mg}^{2+}$, $\mathrm{Ca}^{2+}, \mathrm{Ba}^{2+}, \mathrm{Li}^{+}, \mathrm{Na}^{+}, \mathrm{K}^{+}, \mathrm{Cs}^{+}$) were also studied with the fluorescence spectroscopy. An important reduction in fluorescence emission intensities were seen with the addition of $\mathrm{Cu}^{2+}$ and $\mathrm{Fe}^{3+}$ ions for aminopyrene substituted monospiro/dispiro cyclotriphosphazenes $(6,7)$. The complex stoichiometries of the compounds $(6,7)$ were determined as $2: 1(\mathrm{~L} / \mathrm{M})$ for $\mathrm{Cu}^{2+}$ and as $2: 1(\mathrm{~L} / \mathrm{M}), 1: 1(\mathrm{~L} / \mathrm{M})$ for $\mathrm{Fe}^{3+}$, respectively. In addition, the calculated detection limits of the compounds were found to be low. As a result, this novel aminopyrene substituted monospiro/dispiro cyclotriphosphazenes are a potential selective and sensitive fluorescence chemosensors for $\mathrm{Cu}^{2+}$ and $\mathrm{Fe}^{3+}$ ions, and this chemosensor can be used in various application fields such as health or environment.

\section{References}

1. Allcock, H.R, Recent advances in phosphazene (phosphonitrilic) chemistry, Chemical Reviews, 1972, 72, 315-356.

2. Chandrasekhar, V, Krishnan, V, Advances in the chemistry of chlorocyclophosphazenes, Advances in Inorganic Chemistry, 2002, 53, $159-211$

3. Yıldırım, T, Bilgin, K, Yenilmez Çiftçi, G, Tanrıverdi Eçik, E, Şenkuytu, E, Uludağ, Y, Tomak, L, Kılıç, A, Synthesis, cytotoxicity and apoptosis of cyclotriphosphazene compounds as anti-cancer agents, European Journal of Medicinal Chemistry, 2012, 52, 213220 .

4. Bolink, H.J, Barea, E, Costa, R.D., Coronado, E, Sudhakar, S, Zhen, C, Sellinger, A Efficient blue emitting organic light emitting diodes based on fluorescent solution processable cyclic phosphazenes, $\mathrm{Or}$ ganic Electronics, 2008, 9, 155-163.

5. Moriya, K, Masuda, T, Suzuki, T, Yano, S, Kajiwara, M, Liquid Crystalline Phase Transition in Hexakis (4- $\left(\mathrm{N}-\left(4^{1}\right.\right.$-alkoxyphenyl) iminomethyl) phenoxy) cyclotriphosphazene. Molecular Crystals and Liquid Crystals Science and Technology Section A. Molecular Crystals and Liquid Crystals, 1998, 318(1), 267-278.

6. Davarc1, D, Zorlu, Y, Group 12 metal coordination polymers built on a flexible hexakis(3-pyridyloxy)cyclotriphosphazene ligand: Effect of the central metal ions on the construction of coordination polymers, Polyhedron, 2017, 127, 1-8.

7. Şenkuytu, E, Tanrıverdi Eçik, E, Durmuş, M, Yenilmez Çiftçi, G, Monofunctional amines substituted fluorenylidene bridged cyclotriphosphazenes: 'Turn-off' fluorescence chemosensors for $\mathrm{Cu}^{2+}$ and $\mathrm{Fe}^{3+}$ ions, Polyhedron, 2015, 101, 223-229.
8. Yenilmez Çiftçi, G, Şenkuytu, E, Bulut, M, Durmuş, M, Novel Coumarin Substituted Water Soluble Cyclophosphazenes as "Turn-Off" Type Fluorescence Chemosensors for Detection of $\mathrm{Fe}^{3+}$ ions in Aqueous Media, Journal of Fluorescence, 2015, 25, 1819-1830.

9. Kundu, A, Hariharan, P.S, Prabakaran, K, Anthony, S.P, Synthesis of new colori/ A fluorimetric chemosensor for selective sensing of biologically important $\mathrm{Fe}^{3+}, \mathrm{Cu}^{2+}$ and $\mathrm{Zn}^{2+}$ metal ions, Spectrochimica Acta Part A: Molecular and Biomolecular Spectroscopy, 2015, 151, 426-431.

10. Li, C.Y, Zou, C.X, Li, Y.F, Tang, J.L, Weng, C, A new rhodaminebased fluorescent chemosensor for $\mathrm{Fe}^{3+}$ and its application in living cell imaging, Dyes and Pigments, 2014, 104, 110-115.

11. Wanga, D, Zheng, J.Q, Zhenga, X.J, Fanga, D.C, Yuanc, D.Q, Jin, L.P, A fluorescent chemosensor for the sequential detection of copper(II) and histidine and its biological applications, Sensors and Actuators B, 2016, 228, 387-394.

12. Evstatiev, R, Gasche, C, Iron sensing and signalling, Gut, 2012, 61, 933-952.

13. Que, E.L, Domaille, D.W, Chang, C.J, Metals in Neurobiology: Probing Their Chemistry and Biology with Molecular Imaging, Chemical Reviews, 2008, 108, 1517-1549.

14. Andrews, N, Disorders of Iron Metabolism, The New England Journal of Medicine, 1999, 341, 1986-1995.

15. Squittia, R, Ghidoni, R, Simonelli, I, Ivanova, I.D, Colabufo, N.A, Zuin, M, Benussi, L, Binetti, G, Cassetta, E, Rongioletti, M, Siotto, M, Copper dyshomeostasis in Wilson disease and Alzheimer's disease as shown by serum and urine copper indicators, Journal of Trace Elements in Medicine and Biology, 2018, 45, 181-188.

16. Wang, C, Liu, Y, Cheng, J, Song, J, Zhao, Y, Ye, Y, Efficient FRETbased fuorescen tratiometric chemosensors for Fe3+ and it sapplication in living cells, Journal of Luminescence, 2015, 157, 143-148.

17. Park, G.J, You, G.R, Choi, Y.W, Kim, C, A naked-eye chemosensor for simultaneous detection of iron and copper ions and its copper complex for colorimetric/fluorescentsensing of cyanide, Sensors and Actuators B, 2016, 229, 257-271.

18. Cheng, P.F, Xu, K.X, Yao, W, Xie, E, Liu, J, Novel fluorescent chemosensors based on carbazole for $\mathrm{Cu}^{2+}$ and $\mathrm{Fe}^{3+}$ in aqueous media, Journal of Luminescence, 2013, 143, 583-586.

19. Carriedo, G.A, Catuxo, L.F, Alonso, F.J.G, Elipe, P.G, Gonzalez, P.A, Preparation of a New Type of Phosphazene High Polymers Containing 2,2'-Dioxybiphenyl Groups, Macromolecules, 1996, 29, 5320-5325.

20. Parker, C.A, Rees, W, Correction of Fluorescence Spectra and Measurement of Fluorescence Quantum Efficiency, Analyst, 1960, 85(1013), 587-600. 
Celal Bayar University Journal of Science

Volume 14, Issue 2, p 209-216

E. Senkuytu

\section{Supporting Information}

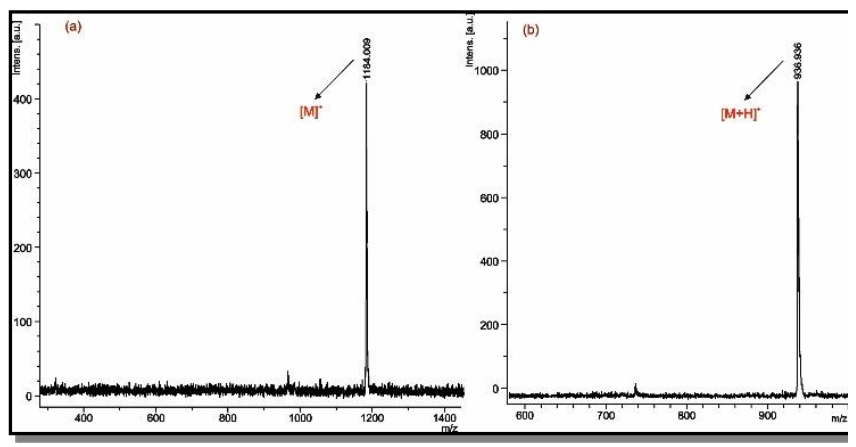

Figure S1. Mass spectrum of (a) Compound 6 and (b) Compound 7.

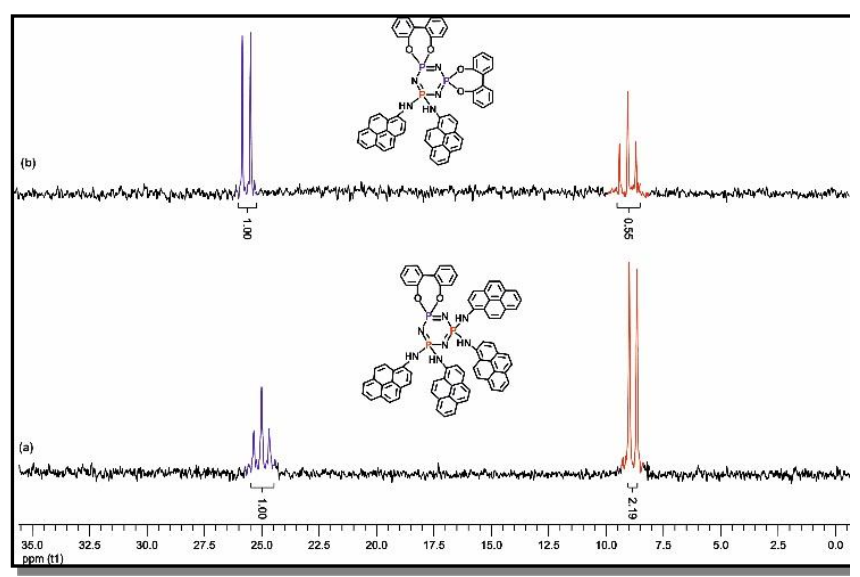

Figure S2. The ${ }^{1} \mathrm{H}$ decoupled ${ }^{31} \mathrm{P}$ NMR spectra in $\mathrm{CDCl}_{3}$ solution (a) compound $\mathbf{6}$; (b) compound 7.

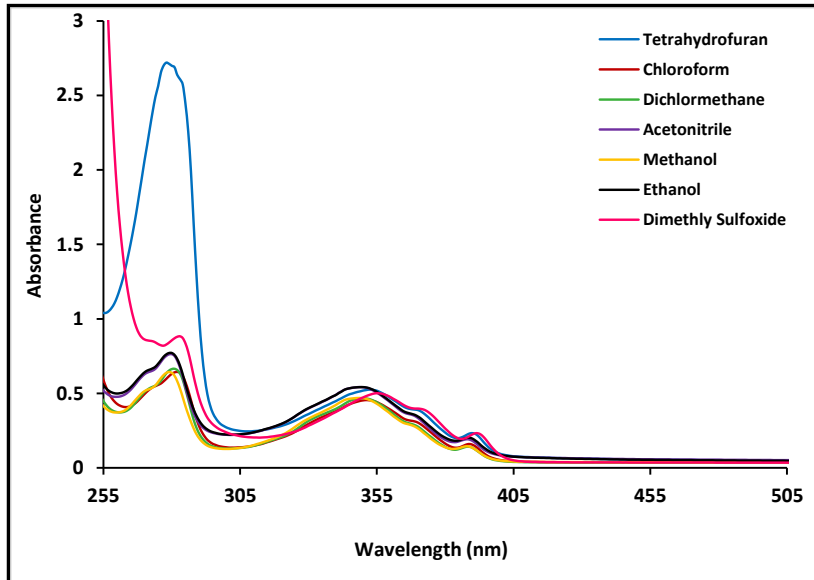

Figure S3: Absorbance spectra of Compound $6(5 \mu \mathrm{M})$ in different solvents.

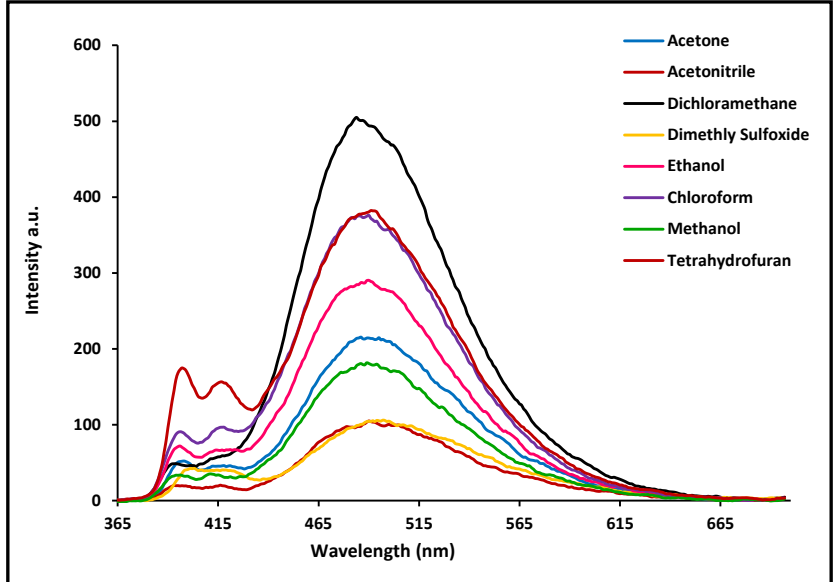

Figure S4. Fluorencence spectra of Compound $6(5 \mu \mathrm{M})$ in different solvents.

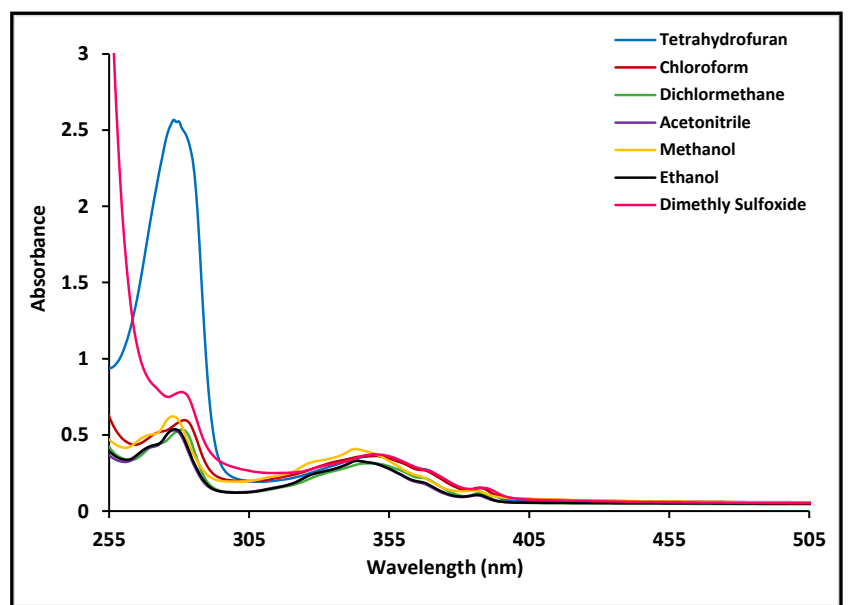

Figure S5. Absorbance spectra of Compound $7(5 \mu \mathrm{M})$ in different solvents.

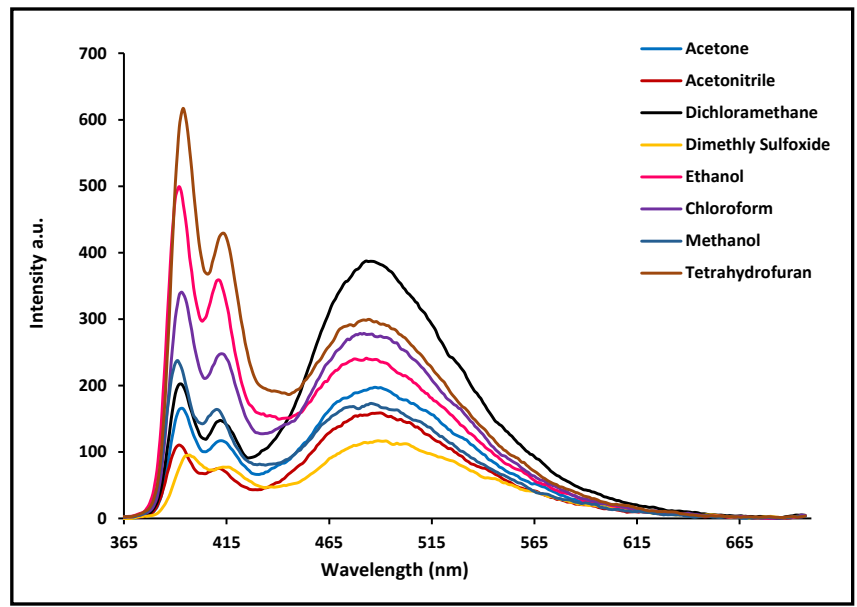

Figure S6. Fluorencence spectra of Compound $7(5 \mu \mathrm{M})$ in different solvents. 


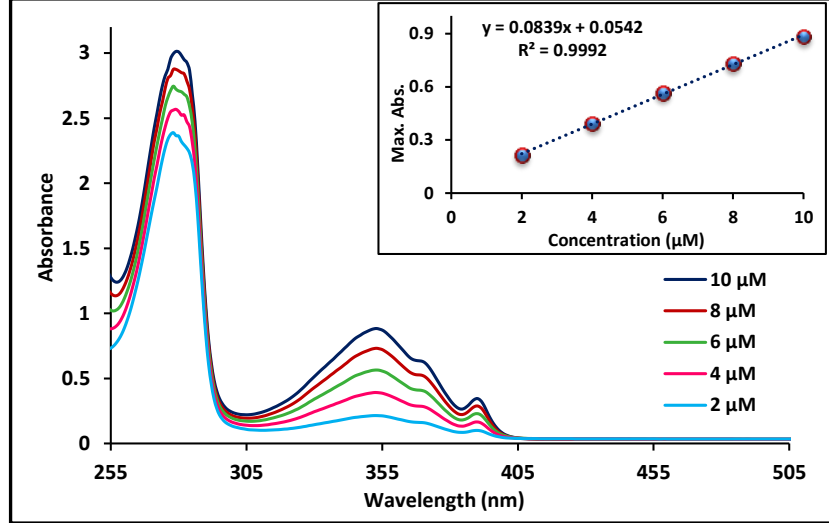

Figure S7. Absorbance spectrum of Compound 6 in THF at different concentration.

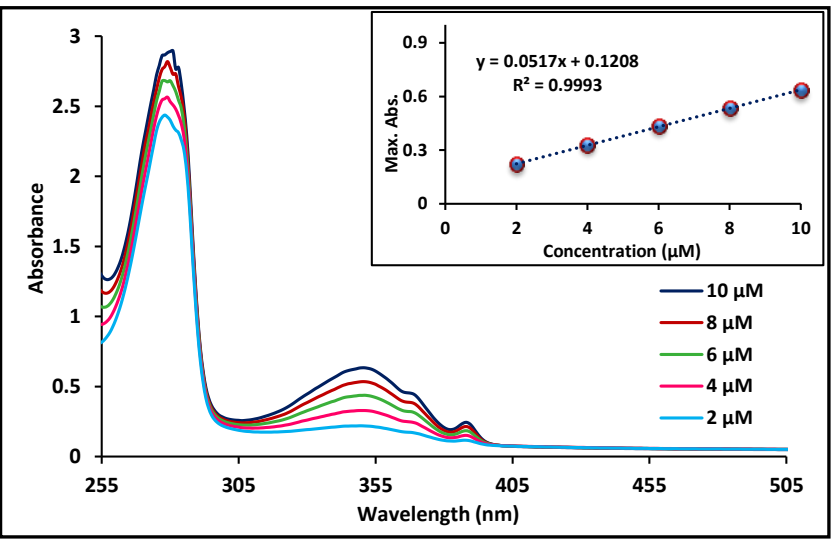

Figure S8. Absorbance spectrum of Compound 7 in THF at different concentration.

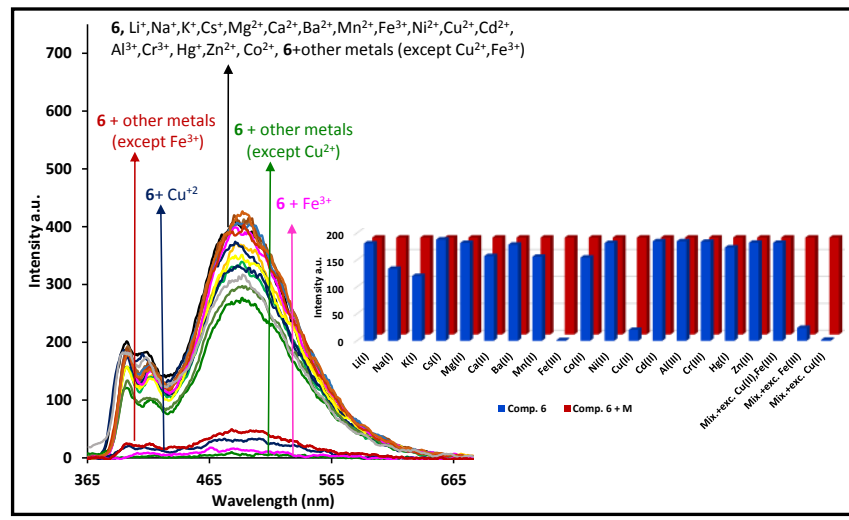

Figure S9. Fluorescence emission spectra of Compound 6 $(5 \mu \mathrm{M}$ in THF) after addition of $10 \mu \mathrm{L}$ of $0.1 \mathrm{M}$ different metal ions (Excitation wavelength $=350 \mathrm{~nm}$ ).
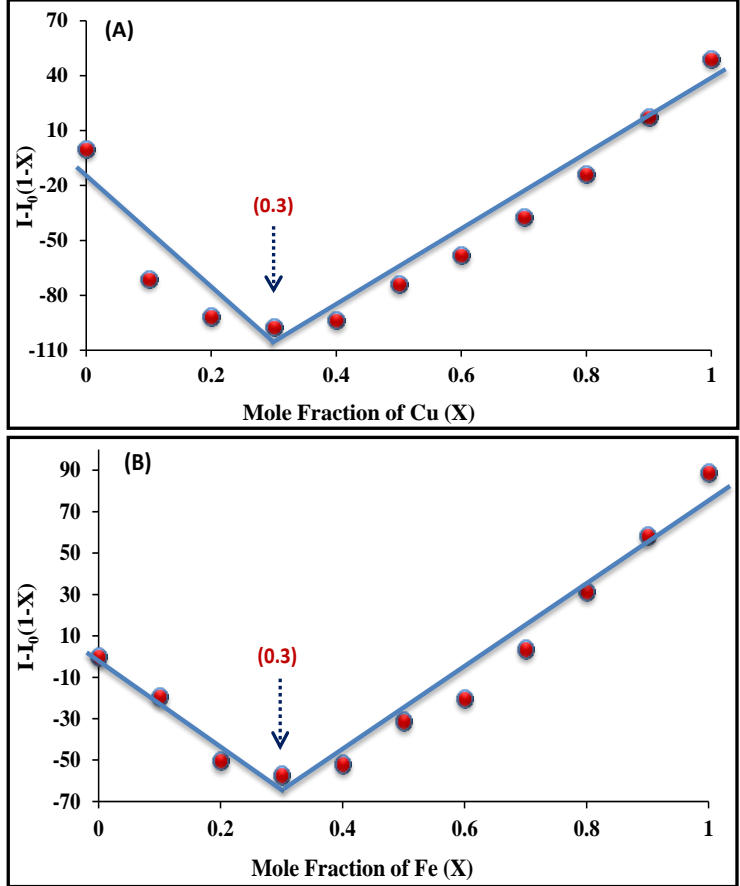

Figure S10. A) Job's plot of fluorescence of $\mathrm{Cu}^{2+}+\mathrm{Com}-$ pound $\mathbf{6}$ complex, B) Job's plot of fluorescence of $\mathrm{Fe}^{3+}+$ Compound $\mathbf{6}$ complex in THF.
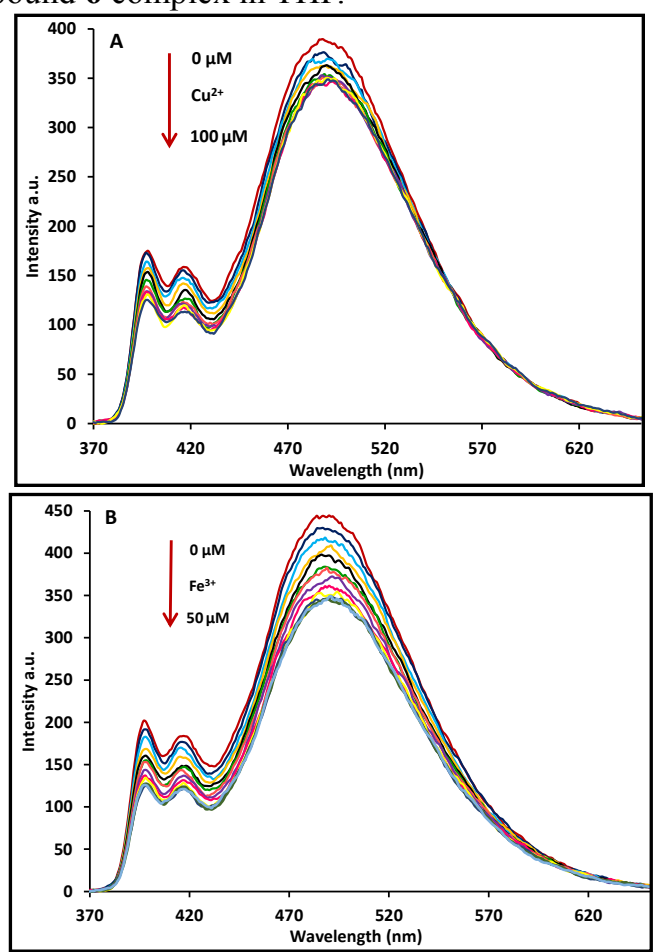

Figure S11. A) Fluorescence titration of Compound 6 (5 $\mu \mathrm{M}$ in THF) with different amount of $\mathrm{Cu}^{2+}$, B) Fluorescence titration of Compound $6(5 \mu \mathrm{M}$ in THF) with different amount of $\mathrm{Fe}^{3+}$ (Excitation wavelength $=350 \mathrm{~nm}$ ). 
Celal Bayar University Journal of Science

Volume 14, Issue 2, p 209-216
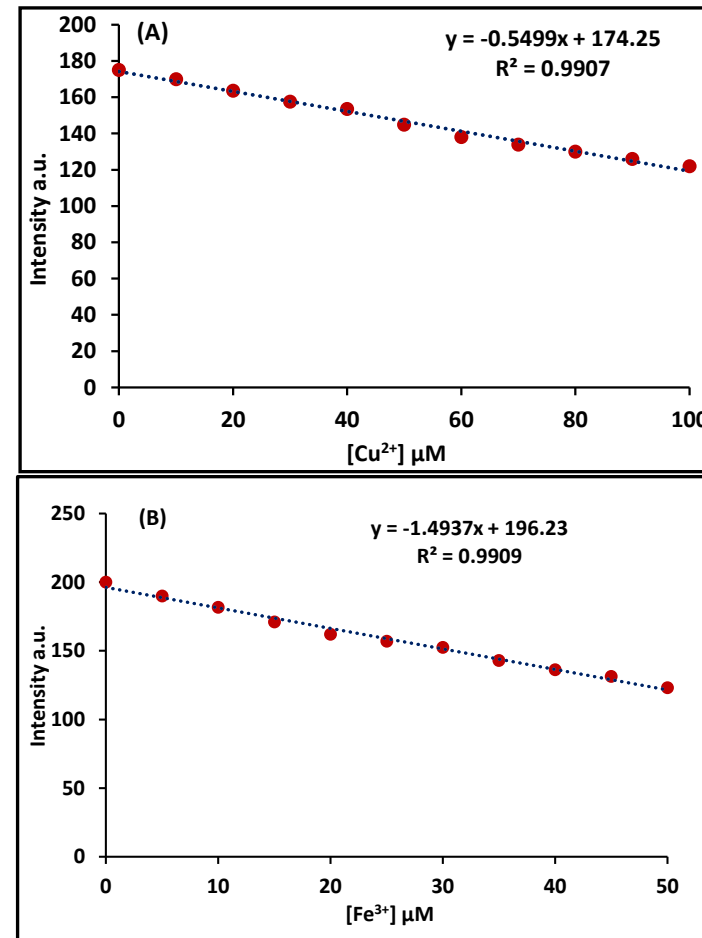

Figure S12. (A) Calibration curve of fluorescence intensity for Compound $6\left(5 \mu \mathrm{M}\right.$ in THF and $\mathrm{Cu}^{2+}(0-100 \mu \mathrm{M})(\mathbf{B})$ Calibration curve of fluorescence intensity for Compound $6\left(5 \mu \mathrm{M}\right.$ in THF and $\mathrm{Fe}^{3+}(0-50 \mu \mathrm{M})$. 